\title{
Could international compulsory licensing reconcile tiered pricing of pharmaceuticals with the right to health?
}

\author{
Gorik Ooms ${ }^{1,2^{*}}$, Lisa Forman ${ }^{3,4}$, Owain D Williams ${ }^{5}$ and Peter S Hill ${ }^{5}$
}

\begin{abstract}
Background: The heads of the Global Fund and the GAVI Alliance have recently promoted the idea of an international tiered pricing framework for medicines, despite objections from civil society groups who fear that this would reduce the leeway for compulsory licenses and generic competition. This paper explores the extent to which an international tiered pricing framework and the present leeway for compulsory licensing can be reconciled, using the perspective of the right to health as defined in international human rights law.

Discussion: We explore the practical feasibility of an international tiered pricing and compulsory licensing framework governed by the World Health Organization. We use two simple benchmarks to compare the relative affordability of medicines for governments average income and burden of disease to illustrate how voluntary tiered pricing practice fails to make medicines affordable enough for low and middle income countries (if compared with the financial burden of the same medicines for high income countries), and when and where international compulsory licenses should be issued in order to allow governments to comply with their obligations to realize the right to health.
\end{abstract}

Summary: An international tiered pricing and compulsory licensing framework based on average income and burden of disease could ease the tension between governments human rights obligation to provide medicines and governments trade obligation to comply with the Agreement on Trade-Related Aspects of Intellectual Property Rights.

Keywords: Right to health, Tiered pricing, TRIPS, Medicines, Patent, Compulsory licensing

\section{Background}

While the heads of the Global Fund and GAVI Alliance promote the idea of a global tiered pricing framework [1], civil society groups are asking them to abandon and dissolve the taskforce that was created to explore and develop this idea originally named the Blue Ribbon Taskforce [2], recently renamed the Equitable Access Initiative [3]. One of these civil society groups is Oxfam, which until recently was a proponent of an international tiered pricing framework [4]. Oxfam s position shift may

\footnotetext{
*Correspondence: gooms@itg.be

'Department of Public Health, Institute of Tropical Medicine, Nationalestraat

155, 2000 Antwerp, Belgium

${ }^{2}$ Law and Development Research Group, Faculty of Law, University of

Antwerp, Antwerp, Belgium

Full list of author information is available at the end of the article
}

be due to the fact that in the international tiered pricing framework it had in mind, the pricing of patentprotected medicines would be set by an international public health body such as the WHO [4], while the Equitable Access Initiative seems to rely ultimately on voluntary discounts by patent-owning companies. For example, Seth Berkley, the CEO of the GAVI Alliance, writes: So although it is for manufacturers to set the prices of vaccines, the tiers would act as a guide irrespective of whether they are multinational corporations or developing country vaccine manufacturers [1].

Thus two quite different models of an international tiered pricing framework can be imagined: one under which prices are ultimately set by patent-owning pharmaceutical companies, with guidance from an internationally agreed set of non-binding principles, the other under which prices are set under WHO governance. Our intention for 
Table 1 Reasonable and real discounts for Atripla

\begin{tabular}{|c|c|c|c|c|}
\hline Country name & GNI discount & HIV prevalence discount & Combined discount & Merck discount \\
\hline Congo, Dem. Rep. & 99.486 & 77.273 & 99.883 & 95 \\
\hline Burundi & 99.463 & 80.769 & 99.897 & 95 \\
\hline Malawi & 99.284 & 97.685 & 99.983 & 95 \\
\hline Liberia & 99.173 & 72.222 & 99.770 & 95 \\
\hline Ethiopia & 99.150 & 80.769 & 99.837 & 95 \\
\hline Niger & 99.128 & 50.000 & 99.564 & 95 \\
\hline Madagascar & 99.038 & 50.000 & 99.519 & 95 \\
\hline Guinea & 99.016 & 85.294 & 99.855 & 95 \\
\hline Eritrea & 98.994 & 64.286 & 99.641 & 95 \\
\hline Uganda & 98.927 & 96.528 & 99.963 & 95 \\
\hline Togo & 98.882 & 91.379 & 99.904 & 95 \\
\hline Central African Republic & 98.860 & 0.000 & 98.860 & 95 \\
\hline Gambia, The & 98.860 & 80.769 & 99.781 & 95 \\
\hline Guinea-Bissau & 98.860 & 93.590 & 99.927 & 95 \\
\hline Mozambique & 98.860 & 97.748 & 99.974 & 95 \\
\hline Tanzania & 98.725 & 95.098 & 99.938 & 95 \\
\hline Sierra Leone & 98.703 & 83.333 & 99.784 & 95 \\
\hline Rwanda & 98.658 & 91.379 & 99.884 & 95 \\
\hline Zimbabwe & 98.547 & 98.299 & 99.975 & 95 \\
\hline Mali & 98.524 & 72.222 & 99.590 & 95 \\
\hline Burkina Faso & 98.502 & 75.000 & 99.625 & 95 \\
\hline Afghanistan & 98.479 & 0.000 & 98.479 & 95 \\
\hline Nepal & 98.435 & 16.667 & 98.696 & 95 \\
\hline Benin & 98.323 & 77.273 & 99.619 & 95 \\
\hline Haiti & 98.301 & 88.095 & 99.798 & 95 \\
\hline Chad & 98.278 & 90.741 & 99.841 & 95 \\
\hline South Sudan & 98.233 & 90.741 & 99.836 & $?$ \\
\hline Bangladesh & 98.122 & 0.000 & 98.122 & 95 \\
\hline Comoros & 98.122 & 88.095 & 99.776 & 95 \\
\hline Kenya & 98.077 & 95.902 & 99.921 & 95 \\
\hline Cambodia & 98.032 & 68.750 & 99.385 & 95 \\
\hline Tajikistan & 98.032 & 16.667 & 98.360 & 92 \\
\hline Kyrgyz Republic & 97.786 & 16.667 & 98.155 & 92 \\
\hline Senegal & 97.697 & 50.000 & 98.848 & 95 \\
\hline Mauritania & 97.518 & 37.500 & 98.449 & 95 \\
\hline Solomon Islands & 97.473 & 0.000 & 97.473 & 95 \\
\hline Cameroon & 97.384 & 94.444 & 99.855 & 95 \\
\hline Cote d Ivoire & 97.272 & 92.188 & 99.787 & 95 \\
\hline Pakistan & 97.182 & 0.000 & 97.182 & 95 \\
\hline Lao PDR & 97.160 & 16.667 & 97.633 & 95 \\
\hline Yemen, Rep. & 97.160 & 0.000 & 97.160 & 95 \\
\hline Sao Tome and Principe & 97.071 & 75.000 & 99.268 & 95 \\
\hline Zambia & 96.981 & 98.031 & 99.941 & 95 \\
\hline Lesotho & 96.914 & 98.918 & 99.967 & 95 \\
\hline
\end{tabular}


Table 1 Reasonable and real discounts for Atripla (Continued)

\begin{tabular}{|c|c|c|c|c|}
\hline Nigeria & 96.780 & 91.935 & 99.740 & 95 \\
\hline Sudan & 96.646 & 0.000 & 96.646 & 95 \\
\hline Ghana & 96.534 & 82.143 & 99.381 & 95 \\
\hline India & 96.534 & 16.667 & 97.112 & $?$ \\
\hline Vietnam & 96.534 & 37.500 & 97.834 & 92 \\
\hline Nicaragua & 96.310 & 16.667 & 96.925 & 92 \\
\hline Uzbekistan & 96.154 & 0.000 & 96.154 & 92 \\
\hline Papua New Guinea & 95.997 & 50.000 & 97.999 & 95 \\
\hline Moldova & 95.371 & 64.286 & 98.347 & 95 \\
\hline Honduras & 95.259 & 50.000 & 97.630 & 95 \\
\hline Bolivia & 95.036 & 16.667 & 95.863 & 92 \\
\hline Bhutan & 94.589 & 0.000 & 94.589 & 95 \\
\hline Philippines & 94.410 & 0.000 & 94.410 & $?$ \\
\hline Kiribati & 94.365 & 0.000 & 94.365 & 95 \\
\hline Congo, Rep. & 94.298 & 91.071 & 99.491 & 95 \\
\hline Swaziland & 93.605 & 99.057 & 99.940 & 95 \\
\hline Sri Lanka & 93.470 & 0.000 & 93.470 & $?$ \\
\hline Morocco & 93.381 & 0.000 & 93.381 & $?$ \\
\hline Egypt, Arab Rep. & 93.336 & 0.000 & 93.336 & $?$ \\
\hline Vanuatu & 93.292 & 0.000 & 93.292 & 95 \\
\hline Guatemala & 93.023 & 64.286 & 97.508 & 95 \\
\hline Mongolia & 92.934 & 0.000 & 92.934 & 92 \\
\hline Micronesia, Fed. Sts. & 92.777 & 0.000 & 92.777 & $?$ \\
\hline Samoa & 92.710 & 0.000 & 92.710 & 95 \\
\hline Georgia & 92.643 & 16.667 & 93.869 & $?$ \\
\hline Paraguay & 92.397 & 16.667 & 93.664 & $?$ \\
\hline Guyana & 92.375 & 80.769 & 98.534 & 95 \\
\hline Indonesia & 92.352 & 37.500 & 95.220 & 92 \\
\hline Ukraine & 92.174 & 72.222 & 97.826 & 95 \\
\hline El Salvador & 91.972 & 58.333 & 96.655 & $?$ \\
\hline Kosovo & 91.950 & 0.000 & 91.950 & $?$ \\
\hline Timor-Leste & 91.905 & 0.000 & 91.905 & 95 \\
\hline Armenia & 91.682 & 0.000 & 91.682 & $?$ \\
\hline Cabo Verde & 91.436 & 0.000 & 91.436 & 95 \\
\hline Albania & 90.988 & 0.000 & 90.988 & $?$ \\
\hline Marshall Islands & 90.966 & 0.000 & 90.966 & $?$ \\
\hline Fiji & 90.809 & 0.000 & 90.809 & $?$ \\
\hline Tunisia & 90.720 & 0.000 & 90.720 & $?$ \\
\hline Tonga & 90.564 & 0.000 & 90.564 & $?$ \\
\hline Angola & 89.758 & 89.130 & 98.887 & 95 \\
\hline Macedonia, FYR & 89.669 & 0.000 & 89.669 & $?$ \\
\hline Jordan & 89.557 & 0.000 & 89.557 & $?$ \\
\hline Bosnia and Herzegovina & 89.378 & 0.000 & 89.378 & $?$ \\
\hline Algeria & 88.775 & 0.000 & 88.775 & $?$ \\
\hline Jamaica & 88.529 & 85.294 & 98.313 & 95 \\
\hline
\end{tabular}


Table 1 Reasonable and real discounts for Atripla (Continued)

\begin{tabular}{|c|c|c|c|c|}
\hline Ecuador & 88.439 & 58.333 & 95.183 & $?$ \\
\hline Thailand & 88.350 & 77.273 & 97.352 & $?$ \\
\hline Serbia & 88.193 & 0.000 & 88.193 & $?$ \\
\hline Turkmenistan & 87.903 & 0.000 & 87.903 & $?$ \\
\hline Dominican Republic & 87.768 & 64.286 & 95.632 & 95 \\
\hline Namibia & 87.455 & 98.120 & 99.764 & 95 \\
\hline Tuvalu & 87.366 & 0.000 & 87.366 & 95 \\
\hline China & 87.209 & 0.000 & 87.209 & $?$ \\
\hline Maldives & 87.142 & 0.000 & 87.142 & 95 \\
\hline Peru & 86.449 & 37.500 & 91.531 & $?$ \\
\hline Iraq & 86.292 & 0.000 & 86.292 & $?$ \\
\hline Azerbaijan & 86.091 & 0.000 & 86.091 & $?$ \\
\hline St. Vincent and the Grenadines & 85.689 & 0.000 & 85.689 & 95 \\
\hline Dominica & 85.599 & 0.000 & 85.599 & 95 \\
\hline Belarus & 85.398 & 37.500 & 90.874 & $?$ \\
\hline Bulgaria & 84.705 & 0.000 & 84.705 & $?$ \\
\hline St. Lucia & 84.593 & 0.000 & 84.593 & 95 \\
\hline Colombia & 84.302 & 50.000 & 92.151 & $?$ \\
\hline Grenada & 83.855 & 0.000 & 83.855 & 95 \\
\hline Montenegro & 83.855 & 0.000 & 83.855 & $?$ \\
\hline South Africa & 83.318 & 98.603 & 99.767 & 95 \\
\hline Botswana & 82.894 & 98.913 & 99.814 & 95 \\
\hline Panama & 80.970 & 64.286 & 93.204 & 95 \\
\hline Romania & 80.859 & 0.000 & 80.859 & $?$ \\
\hline Mauritius & 80.836 & 79.167 & 96.008 & 92 \\
\hline Suriname & 80.590 & 77.273 & 95.589 & 95 \\
\hline Costa Rica & 80.277 & 16.667 & 83.564 & $?$ \\
\hline Lebanon & 79.450 & 0.000 & 79.450 & $?$ \\
\hline Mexico & 78.444 & 0.000 & 78.444 & $?$ \\
\hline Kazakhstan & 78.131 & 0.000 & 78.131 & $?$ \\
\hline Malaysia & 78.041 & 37.500 & 86.276 & $?$ \\
\hline Palau & 77.952 & 0.000 & 77.952 & $?$ \\
\hline Gabon & 77.549 & 93.750 & 98.597 & 95 \\
\hline Turkey & 75.783 & 0.000 & 75.783 & $?$ \\
\hline Brazil & 73.994 & 0.000 & 73.994 & $?$ \\
\hline Seychelles & 72.764 & 0.000 & 72.764 & 92 \\
\hline Hungary & 72.250 & 0.000 & 72.250 & $?$ \\
\hline Venezuela, RB & 72.138 & 58.333 & 88.391 & $?$ \\
\hline
\end{tabular}

this paper is not to explore whether the Equitable Access Initiative is leaning more towards one model or the other. Our intention is to explore the practical feasibility of the model under which prices are set under WHO governance, using international compulsory licenses as a way to make a set of equitable pricing principles binding.

\section{Discussion}

Before we explain the international tiered pricing an compulsory licensing framework we have in mind, we need to unpack three concepts:

- By the right to health, we mean the entitlement of all humans to organized efforts from society that 
promote and improve health, and the corresponding obligations to meet those entitlements as born by governments and the international community, as enshrined in international human rights law;

- By compulsory license, we mean a legally sanctioned government action that obliges the owner of a patent to allow another company to produce and distribute a generic equivalent of the patentprotected medicine;

- By tiered pricing, we mean the practice of setting different prices for different groups of potential buyers.

\section{The right to health}

The right to health has been enshrined in several treaties, but we focus on the International Covenant on Economic, Social and Cultural Rights (Covenant) for two reasons. Firstly, because it has been endorsed by more states than regional human rights treaties, such as the African Charter on Human and Peoples Rights; and secondly because it has a wider scope than treaties that confirm the right to health for specific groups, like the Convention on the Rights of the Child or the Convention on the Elimination of All Forms of Discrimination Against Women. The Covenant confirms the right of everyone to the enjoyment of the highest attainable standard of physical and mental health (article 12(1)) and it confirms that every state is obliged to take steps, individually and through international assistance and cooperation, especially economic and technical, to the maximum of its available resources, with a view to achieving progressively the full realization of the right to health and other rights recognized in the Covenant (article 2(1)). The Committee on Economic, Social and Cultural Rights that was created to monitor states compliance with the Covenant further clarified that states have a core obligation to ensure the satisfaction of, at the very least, minimum essential levels of each of the rights enunciated in the Covenant, including essential primary health care, and that these core obligations include at least ensuring the right of access to health facilities, goods and services on a non-discriminatory basis, especially for vulnerable or marginalized groups, and providing essential medicines as defined by WHO [5]. To be sure, this is about the minimum obligation, which applies to all countries, regardless of their income levels: the general legal obligation to realize the right to health progressively extends beyond essential medicines to a general duty to ensure access to all medicines that may improve peoples health. Finally, the Committee clarified that it is particularly incumbent on States parties and other actors in a position to assist, to provide international assistance and cooperation, especially economic and technical which enable developing countries to fulfil their core and other obligations [5].

\section{Compulsory licenses}

To become or remain a member of the World Trade Organization (WTO), states have to comply with the Agreement on Trade-Related Aspects of Intellectual Property Rights (TRIPS Agreement) [6]. The TRIPS Agreement obliges WTO members to adopt certain minimum levels of intellectual property protection in their law, national or regional, including patents for new and innovative medicines. A patent gives its owner exclusive rights to the patent-protected medicine: in principle, only the patent-owner can authorize the manufacturing or importation and the distribution of the medicine that is protected by the patent, in the territory covered by the patent. This can put governments in a conflicted position: one the one hand, they have a legal obligation to ensure the provision of the medicines that people need (as discussed above); on the other hand, they may have to grant patents on new and innovative medicines, which gives the patent-owner an effective monopoly (and as a result, power over the price), unless governments use exceptional measures as we will explain below. Governments can negotiate the price of a medicine with the patent-owner, but have no guarantee that such negotiations will result in reasonable prices, especially if their home market is relatively insignificant to the patent-holding firm. However, the exclusive rights that are attached to a patent are not absolute: the TRIPS Agreement foresees several exceptions, of which we will discuss only compulsory licenses here. A compulsory license is a legally sanctioned government decision that obliges the patentowner to provide a license to another company, allowing that other company to manufacture a generic equivalent of the medicine in question. That generic equivalent can then be distributed, under a different brand name and usually at a much cheaper price than the one set by the patent-owner. In practice, the patent-owner does not have to follow through and issue a license to a third company; the compulsory license simply signals that the patent-owner will no longer be able to oppose the manufacturing and distribution of the generic equivalent by the company appointed by the government.

Thus the threat of a possible compulsory license often works as the stick behind the door in price negotiations between governments and patent-owning companies. If no agreement is reached with regard to securing lower prices, governments can issue a compulsory license. This tool has been used effectively by countries that have domestic manufacturing capacity.

In countries that do not have domestic manufacturing capacity, however, compulsory licenses have proven less effective with regard to securing lower prices. This is due to the fact that the reach of a compulsory license is limited to the territory of the government that issues it. 
The government of a given country could, in theory, issue a compulsory license for a given medicine to a manufacturer based in another country, but that license has no legal validity in that other country. So if the given medicine is protected by a patent in that other country, the manufacturer would still not be allowed to produce the generic equivalent, even if it is for export purposes only. A second compulsory license, issued by the government of the country where the manufacturer is located, would be required. And that is difficult because of TRIPS Agreement requirement that compulsory licensing be predominantly for the supply of the domestic market [6].

The public outrage created by some excessively stringent interpretations of the TRIPS Agreement forced the WTO to adopt, in Doha in 2001, a Declaration on the TRIPS Agreement and Public Health, which confirmed that the TRIPS Agreement does not and should not prevent Members from taking measures to protect public health, and that every state has the right to grant compulsory licenses and the freedom to determine the grounds upon which such licenses are granted [7]. The Doha Declaration also called for a solution to the problem explained above: the requirement that compulsory licensing be predominantly for the supply of the domestic market, which particularly affects least developed countries without local manufacturing capacity. As a result, the WTO General Council released a decision in August 2003, waiving the for domestic purposes only requirement, thus permitting developing countries to import generic medicines produced under compulsory licenses issued for export purposes [8]. This decision was formalized in December 2005 and will if ratified by a sufficient number of WTO members create a special compulsory license system in which an importing country would notify the WTO of its intention to use the system, while the exporting country would grant a compulsory license to export pharmaceuticals to the country in question [9]. Until then the deadline for ratification has been extended until December 2015 the August 2003 waiver remains valid.

So far, this special compulsory license regime in the making has only been used once in 2007, when a Canadian generic manufacturer obtained permission to export antiretroviral medicines to Rwanda. The manufacturer made only two shipments of drugs to Rwanda over a six year period and declined to renew the license because of the complexity, cost and limited duration of the license [10]. Legislative efforts to streamline the licensing process were voted down twice in Canadian parliament, at least in part because of pharmaceutical industry opposition [11]. Furthermore, this special compulsory license regime limits the competition between potential generic manufacturers to those based in countries that issue compulsory licenses, and thus has only limited effect on market prices.

\section{Tiered pricing}

In essence, tiered pricing indicates the practice of setting different prices for different groups tiers of potential buyers or national markets. As an illustration of this practice, McDonalds sets different prices for hamburgers sold in New York and in Johannesburg. In theory, tiered pricing is completely unrelated to patent protection and compulsory licenses. When a company applies for a patent, the outcome of that application does not depend on whether or not the company commits to tiered pricing. And when a government is in a position to issue a compulsory license, the commitment of the patent-owner to tiered pricing or the absence thereof does not affect the right of the government to issue a compulsory license. Yet when tiered pricing is discussed in the context of medicines, it is usually presented as an alternative for, or a correction to, the present intellectual property regime for medicines. The idea is that tiered pricing in accordance with a widely endorsed set of principles would provide a middle ground between prices arbitrarily set by patent-owning companies, and compulsory licenses arbitrarily issued by governments [12].

\section{An international tiered pricing and compulsory licensing framework}

For compulsory licenses to have the same stick behind the door effect on price negotiations in countries without domestic manufacturing capacity as they have in countries with domestic manufacturing capacity they should have an international reach. We suggest that an international tiered pricing and compulsory licensing framework could be created through a convention in accordance with article 19 of the WHO constitution. According to article 19, the WHA shall have authority to adopt conventions or agreements with respect to any matter within the competence of the Organization , and [a] two-thirds vote of the Health Assembly shall be required for the adoption of such conventions or agreements, which shall come into force for each Member when accepted by it in accordance with its constitutional processes [13]. At present, a two thirds vote means 130 members out of 194 members. It is possible therefore that a WHO Convention on International Tiered Pricing and Compulsory Licensing (Convention) could lay out the principles needed to calculate reasonable prices for patent-protected medicines. This Convention would not have the power to impose these prices upon patentowning companies directly, but it could do so indirectly, by promoting and facilitating international compulsory licensing whenever a patent-owner charges prices above the reasonable level. The Convention as we imagine it would appoint a panel that could issue international compulsory licenses upon the request of governments that were unable to negotiate reasonable prices with the 
patent-owning companies. This would go a long way to solving the problems faced in the Canada and Rwanda example detailed above. Once issued, these compulsory licenses would be considered valid in all counties that have ratified the Convention, which would allow all companies with manufacturing capacity for the medicine in question to submit a bid to the government that successfully requested the international compulsory license thus creating competition between all companies with manufacturing capacity for the medicine in question that are based in one of the countries that ratified the Convention. Once the purchasing country made its choice, the government of the country where the manufacturer is based would issue a final compulsory license, to satisfy the WTO requirement that the exporting country grant a compulsory license to export pharmaceuticals (but that would be a mere formality).

To make our suggestion less abstract, we considered a very rudimentary set of principles, based on two criteria often used in tiered pricing debates: GNI per capita and burden of disease [12]. (Obviously, more sophisticated set of principles could and probably should be developed and included in the Convention.) We then applied these principles to one particular medicine: Atripla, which is considered as the ideal first line antiretroviral therapy for developing countries, but still not used as such in many countries because of the price [14]. Based on its desirability and pricing, we can assume that the Global Fund will make access to this medicine a priority for the Equitable Access Initiative. Furthermore, since Atripla is a medicine for people living with AIDS, and reliable HIV/AIDS prevalence data are easy to find, the drug is a good candidate for our exercise which is merely an illustration, not a comprehensive analysis. According to the 2013 Untangling the Web of Antiretroviral Price Reductions report of M?decins Sans Fronti?res, Merck sells Atripla at US\$613 per person per year to several Category 1 developing countries, and at $\$ 1,003$ per person per year to a few Category 2 developing countries [15]. The cheapest generic equivalent costs $\$ 158$ per person per year. Which of these prices is the most reasonable?

To answer the question, we first looked up the price for Altripla in Belgium: 822.17 for 30 days [16], which makes 10,003 per year, or $\$ 12,530$ per year. Thus in comparison to Belgium, Category 2 countries receive a 92\% discount, while Category 1 countries receive a 95\% discount. The cheapest generic equivalent results in a 99\% discount.

Then we considered that all developing countries should receive a first discount based on their Gross National Income (GNI) per capita, because the GNI per capita provides an approximation of potential government revenue, and therefore of potential government ability to purchase and distribute or subsidize medicines.
For example, if the GNI per capita of Brazil is $\$ 11,630$, while the GNI per capita of Belgium is $\$ 44,720$, according to World Bank data [17], the ability of the Government of Brazil to purchase or subsidize Atripla (and other medicines) is considered to be at $26 \%$ of the ability of the Government of Belgium, and we assumed that Brazil ought to receive a first discount of $74 \%$. (According to the 2013 Untangling the Web of Antiretroviral Price Reductions report of M?decins Sans Fronti?res, the Government of Brazil receives no systematic discount: it is neither a Category 1 nor a Category 2 country for Merck.)

Then we considered that all developing countries should receive a second discount in accordance with the prevalence of the disease for which the medicine is needed in this case, adult HIV prevalence. The justification for this second discount is again based on countries ability to pay for medicines: at equal potential government revenue, a country that has to provide AIDS treatment to 10 out of 100 inhabitants can afford to pay per patient only $10 \%$ of what a country that has to provide AIDS treatment to 1 out of 100 inhabitants can pay. The first country therefore ought to receive an additional 90\% discount. Again we looked at World Bank data [17], except for the reference country (Belgium) because the World Bank database does not include an HIV prevalence estimate for Belgium. According to the epidemiological factsheet generated by the UNAIDS website, the adult HIV prevalence in Belgium is $0.25 \%$ [18]. For countries for which the World Bank database does not include an estimate of adult HIV prevalence, we assumed for the sake of this exercise that HIV prevalence is not significantly high enough to warrant an additional discount.

According to our estimates, represented in Table 1, only 13 out of the 127 developing countries we included receive a reasonable discount from Merck: a discount that results in a financial burden that does not exceed the financial burden on the Government of Belgium if we take GNI per capita and adult HIV prevalence into account. These countries are: Bhutan, Kiribati, Vanuatu, Samoa, TimorLeste, Cabo Verde, Tuvalu, Maldives, St Vincent and the Grenadines, Dominica, St Lucia, Grenada, Panama, and The Seychelles. Under the Convention proposed here, they could still issue a (domestic) compulsory license but would not obtain an international compulsory license.

The other 114 countries could, under the Convention proposed here, apply for an international compulsory license. A panel of experts under WHO governance would verify GNI and HIV prevalence data, and perhaps give Merck a final chance to adjust its tiered pricing in accordance with the principles of the Convention. If that were unsuccessful the panel would issue an international compulsory license. 
If an international compulsory license would result in a $99 \%$ discount, even that would not be sufficient for 39 countries: they would need additional assistance from the Global Fund, for example.

Most of the other 75 countries (out of the 114 countries for which the present Merck discount is insufficient) could pay the price of the cheapest generic equivalent without facing a higher relative financial burden than the Government of Belgium; some could even pay up to four times the cost of the cheapest generic equivalent without facing a higher relative financial burden than the Government of Belgium. Mauritius, for example, would according to our estimates be able to pay $4 \%$ of the price for Belgium but receives only a $92 \%$ discount (instead of a $96 \%$ discount). If the Convention panel would issue an international compulsory license for Mauritius (or another country in a similar situation), it could stipulate that some royalties would have to be paid.

So far, our proposal was based on the assumption that the price for Belgium is indeed reasonable, and can be used to calculate reasonable tiered pricing for developing countries, which may not be the case for all new medicines [19]. The Convention could also allow the panel to use, at times, a cost-based yardstick approach [20]: demanding information about the real cost of a medicine, setting a reasonable reference price for high income countries, then calculating reasonable prices for middle and low income countries accordingly. Thus even high income countries could benefit from this Convention, which may increase the likelihood of obtaining 130 votes in favor at the WHA.

Finally, we would argue, in line with Elliott, that facilitating compulsory licensing of pharmaceuticals is, in the given circumstances, a matter of legal obligation under article 2(1): states are indeed obliged to take steps, individually and through international assistance and co-operation, especially economic and technical, to realize the right to health, and facilitating compulsory licensing for countries that needed it is but one of these steps [21].

\section{Summary}

In summary, we would argue that Berkleys assumption, according to which it is for manufacturers to set the prices of vaccines [and medicines] [1], is made too hastily. This assumption is probably based on thinking that no technical solution can be found within the present scope of the international intellectual property regime that could force patent-owners to accept guidelines set by international organizations. But as we demonstrated here, there is a solution, and a relatively simple one too. What it takes is the political will of WHO and 130 of its member states. Whether this political will exists is food for a different debate.

\section{Abbreviations}

GNI: Gross National Income; TRIPS Agreement: Agreement on trade-related aspects of intellectual property rights; WTO: World trade organization.

\section{Competing interests}

Gorik Ooms was funded 1700 Euros and travel expenses by Janssen Pharmaceutica to attend an Experts Round Table in Amsterdam, August 21 22, 2013, for the purpose of evaluating, discussing and advising JANSSEN regarding new and/or existing clinical or market developments, techniques and/or strategies (the Consulting Services) involving Access, Affordability and Pricing in Developing Countries. The funds were paid to his employer ITM, Antwerp. Janssen have had no influence in the formulation of this paper or its analysis. Owain Williams has a contract with the United Nations Development Program (UNDP) to undertake an analysis of the implications of tiered pricing on developing countries, based on his research experience in the broader field and his recent book: Hans Lofgren and Owain David Williams (eds.) The New Political Economy of Pharmaceuticals in the Global South (Basingstoke: Palgrave Macmillan, 2013). This paper is independent of that contract and the analysis undertaken for this paper is separate and distinct from the work commissioned by the UNDP. UNDP has had no role in the development of this paper, and the opinions expressed in it do not reflect their opinions. Peter Hill and Lisa Forman have no conflict of interests or competing interests.

\section{Authors contributions}

GO conceptualized the initial analysis undertook the primary analysis and is responsible for the completion of the manuscript. OW, PSH, and LF have engaged in progressive critique of the paper and subsequent revisions. All authors have read the final manuscript and approve its contents and submission.

\section{Authors information}

GO is a human rights lawyer, and researcher at the Institute of Tropical Medicine, Antwerp, and at the University of the Western Cape, Cape Town. LF is a human rights lawyer and Assistant Professor at the Dalla Lana School of Public Health, University of Toronto.

ODW is an international relations scholar and Visiting Fellow at the School of Population Health, The University of Queensland.

PSH is a public health physician and Associate Professor, Global Health Systems at the School of Population Health, The University of Queensland.

\section{Acknowledgements}

This analysis was undertaken as part of Go4Health, a research project funded by the European Union s Seventh Framework Program, grant HEALTH-F12012-305240, the Australian Government s NH\&MRC-European Union Collaborative Research Grants, grant 1055138 and the Canadian Institutes of Health Research Operating Grant Ethics, grant EOG 131587.

\section{Author details}

${ }^{1}$ Department of Public Health, Institute of Tropical Medicine, Nationalestraat 155, 2000 Antwerp, Belgium. 'Law and Development Research Group, Faculty of Law, University of Antwerp, Antwerp, Belgium. ${ }^{3}$ Dalla Lana School of Public Health, University of Toronto, Toronto, Canada. ${ }^{4}$ Munk School of Global Affairs, University of Toronto, 155 College Street, Toronto M5T 3M7, Ontario, Canada. ${ }^{5}$ School of Population Health, The University of Queensland, Herston Road, Brisbane 4006, Australia.

Received: 8 September 2014 Accepted: 8 December 2014 Published online: 18 December 2014

\section{References}

1. Berkley S: Improving access to vaccines through tiered pricing. Lancet 2014, 383(9936):2265 2267.

2. Open Letter from Civil Society to Mark Dybul, Executive Director of the Global Fund to fight AIDS, Tuberculosis and Malaria. [http://infojustice. org/wp-content/uploads/2014/05/GF-tier-pricing-letter-Final-May13.pdf]

3. Balasubramaniam T: Former WTO Director-General, Pascal Lamy, mooted to chair Global Fund's Equitable Access Initiative. Knowledge Ecology International blog, November 11, 2014. [http://keionline.org/node/2123]

4. Oxfam, Save The Children, VSO: Beyond philanthropy: the pharmaceutical industry, corporate social responsibility and the developing world. 
[http:/www.savethechildren.org.uk/sites/default/files/docs/

Beyond_Philanthropy_1.pdf]

5. Committee on Economic, Social and Cultural Rights: General comment 14: the right to the highest attainable standard of health. [http://www1.umn. edu/humanrts/gencomm/escgencom14.htm]

6. World Trade Organization: Agreement on trade-related aspects of intellectual property rights. [http://www.wto.org/english/docs_e/legal_e/27-trips.pdf]

7. World Trade Organization: Declaration on the TRIPS agreement and public health. [http://www.wto.org/english/thewto_e/minist_e/min01_e/ minded_trips_e.pdf]

8. World Trade Organization: Implementation of paragraph 6 of the Doha Declaration on the TRIPS agreement and public health. [http://www.wto. org/english/tratop_e/trips_e/implem_para6_e.htm]

9. World Trade Organization: Amendment of the TRIPS agreement. [http://www.wto.org/english/tratop_e/trips_e/wtl641_e.htm]

10. Apotex: Submission to the Standing Committee on Industry, Science and Technology: Bill C-393, an act to amend the patent act (drugs for international humanitarian purposes) and to make a consequential amendment to another Act. [http://www.apotex.com/global/docs/ submission_order_en.pdf]

11. Galloway G: Tories block bid to make cheaper medicines for poor nations. In Globe and Mail. 2012 [http://www.theglobeandmail.com/news/ politics/tories-block-bid-to-make-cheaper-medicines-for-poor-nations/ article5759286/]

12. Feldman J: Compulsory licenses: the dangers behind the current practice. J Int Bus Law 2009, 8:137 167.

13. WHO: Constitution of the World Health Organization. [http://apps.who.int/ $\mathrm{gb} / \mathrm{bd} / \mathrm{PDF} / \mathrm{bd} 47 / \mathrm{EN} /$ constitution-en.pdf]

14. Kenyon C, Colebunders $R$ : What is the optimal first line antiretroviral therapy in resource-limited settings? PLoS Med 2012, 9:e1001291.

15. M?decins Sans Fronti?res: Untangling the web of antiretroviral price reductions. [http://d2pd3b5abq75bb.cloudfront.net/2013/09/11/10/25/44/ 896/MSF_Access_UTW_16th_Edition_2013.pdf]

16. Belgian Center for Pharma-Therapeutic Information: Commented Medicines Repertory. [http://www.bcfi.be/]

17. World Bank: Data. [http://data.worldbank.org/]

18. UNAIDS: Regions and Countries. [http://www.unaids.org/en/ regionscountries/countries/belgium/]

19. Hill A, Khoo S, Fortunak J, Simmons B, Ford N: Minimum costs for producing hepatitis $C$ direct-acting antivirals for use in large-scale treatment access programs in developing countries. Clin Infect Dis 2014, 58(7):928 936.

20. Fellows $G K$, Hollis A: Funding innovation for treatment for rare diseases: adopting a cost-based yardstick approach. Orphanet J Rare Dis 2013, 8:180

21. Elliott R: Managing the Market for Medicines Access: Realizing the Right to Health by Facilitating Compulsory Licensing of Pharmaceuticals A Case Study of Legislation and the Need for Reform. In Access to Medicines as a Human Right. Edited by Forman L, Kohler JK. Toronto: University of Toronto Press; 2012.

doi:10.1186/s12914-014-0037-4

Cite this article as: Ooms et al:: Could international compulsory

licensing reconcile tiered pricing of pharmaceuticals with the right to health? BMC International Health and Human Rights 2014 14:37.

\section{Submit your next manuscript to BioMed Central and take full advantage of:}

$\bigotimes$ Convenient online submission

$\otimes$ Thorough peer review

$\nabla$ No space constraints or color $\nabla$ gure charges

$\otimes I m m e d i a t e$ publication on acceptance

\Inclusion in PubMed, CAS, Scopus and Google Scholar

$\otimes$ Research which is freely available for redistribution 